\title{
Secular Trends in Body Dimensions among Young Tennis Players from 1992 to 2008
}

\author{
Tendencias Seculares en las Dimensiones Corporales entre Tenistas Jóvenes desde 1992 hasta 2008
}

\author{
"Ales Filipcic; "Bojan Leskosek; ${ }^{* *}$ Nejc Sarabon \& ${ }^{* *}$ Tjasa Filipcic
}

FILIPCIC, A.; LESKOSEK, B.; SARABON, N. \& FILIPCIC, T. Secular trends in body dimensions among young tennis players from 1992 to 2008. Int. J. Morphol., 30(4):1558-1568, 2012.

SUMMARY: Several studies have examined both physical characteristics and fitness of children and youth. The aim of the study was first, to find the tendency of changes in selected morphological characteristics of young male and female tennis players of various ages in the periods 1992-2000-2008; and second, to find the changes in selected variables of young tennis players and to compare them with the results of boys and girls of same age from normal school population. Sample of variables included body height, body weight and body mass index (BMI). Multivariate analysis of variance revealed statistically significant differences in all main factors (group, age, gender and period) and additionally in interactions group*period, group*gender and age*gender. Univariate analysis of variance revealed statistically significant differences in body height and BMI between the groups of tennis players and the same age school population for both sexes and between three age groups (12-13 years, 14-15 years, 16-17 years) for body height, body weight and BMI. Differences between the sexes indicate statistically significant differences only in variables body height and weight. Changes in the observed morphological characteristics point to the increase in body height, body weight and BMI values in both school population and young tennis players.

KEY WORDS: Young tennis players; Body weight; Body height; BMI; Secular trends.

\section{INTRODUCTION}

As a result of negative tendencies in the physical and motor development of children and youth, the monitoring of development has throughout the developed world become an irreplaceable system, enabling the collection of data and providing up-to-date information, which can be used for efficient approach to problem solving of the above issue (Starc, 2010).

Research in the monitoring of physical and motor development in Slovenia started in 1970 (Sturm \& Strel, 1985). Since 1986 systematic annual measurements of children and youth have been carried out with the use of special database Sports-education chart. Some other European countries have been carrying out similar monitoring of children and youth, although in a less systematic way, on a less regular basis and on a smaller sample of subjects. A special database on physical development has also been maintained by the World Health
Organisation, which uses data from different countries in order to examine growth and development index of children over longer periods of time (WHO, 2004).

Numerous studies have been carried out in the field of morphological characteristics of young people, most often analysing changes in physical characteristics, such as body weight, body height, BMI, percentage of fat tissue etc. Several studies have examined both physical characteristics and physical fitness. Changes to a great extent depend on the time period of research; therefore, the review of such studies will be presented in chronological order.

Lindgren \& Hauspie (1989) have carried out a 10year long longitudinal analyses between 1933 and 1963 and found that body height in 10-year-old children increased by $1 \mathrm{~cm}$ in each decade and in 13-year-old

\footnotetext{
* University of Ljubljana, Faculty of Sport, Ljubljana, Slovenia.

${ }^{* *}$ University of Primorska, Science and Research Centre, Koper, Slovenia.

*** University of Ljubljana, Faculty of Education, Ljubljana, Slovenia.
} 
children by 1 to $2 \mathrm{~cm}$. BMI values have remained relatively constant between 1943 and 1963 . Troiano et al. (1995) have found that the overweight prevalence increased during the examined period among all gender and age groups with the increase being largest between 1976 to 1980.

Stefancic et al. (1996) have compared the results of measurements of physical characteristics for years 1981 and 1982 with the results for years 1991 and 1992. They found a gradual decline of acceleration of physical characteristics in comparison to previous decades. The disproportion between stature and weight gain continues. Menarche in girls started at the age of 12 years and 11 months. The greatest growth spurt remained between the ages of 13 and 14 in boys and a year earlier in girls. The study confirmed the specific early pubertal development in girls, accompanied by an earlier physical development. Growth spurt in girls happened on average 2 years earlier than in boys. Body weight and height clearly show positive secular trend: at the time of children entering puberty, their initial height and weight are larger in comparison to their peers from the 1960s; they also have greater annual increase. Freedman et al. (1997) have found that the yearly increases in relative weight and obesity during 1983 through 1994 were 50\% greater than those between 1973 and 1982.

The level of physical fitness, which Rowlands et al. (1998) divided into neuromotor and aerobic fitness has in the previous decades most often decreased. Their study found a positive relationship between the activity and fitness and suggested a negative relationship between fatness and activity. Similar conclusions can also be seen in a study by Kim et al. (2005), who found an inverse relationship between physical fitness and obesity overweightness among school-aged children.

In a cross-sectional study, Rasmussen et al. (1999) found a 2.4-times increase in the prevalence of overweightness among 18-year-old males over the studied period - from $6.9 \%$ in 1971 to $16.3 \%$ in 1995 . Dollman et al. (1999) have found that 10- and 11-year-old monitored children in the year 1997 were heavier $(1.4-2.9 \mathrm{~kg})$, had a higher BMI $\left(0.13-0.30 \mathrm{~kg} / \mathrm{m}^{2}\right)$ and were slower over a $1.6 \mathrm{~km}$ distance (38 - $48.5 \mathrm{~s})$, compared to children in 1985. Wedderkopp (2001) has found that during the last decade obese children and adolescents have become even more obese and that they have increased in number.

A cross-sectional study by Westerstahl et al. (2003) revealed a decreased aerobic fitness among adolescents between 1974 and 1995 . These changes were partly a result of an increased BMI. However, a decrease in daily physical activity level cannot be excluded as a contributing factor to the decreased aerobic fitness.

Strel et al. (2003a) have monitored physical fitness in development between the years 1990 and 2000. The study included $90 \%$ of primaryschool pupils and $70 \%$ of high school pupils, aged between 7 to 19 . Changes in the observed period were significant and diverse: pupils of both gender are significantly taller, a noticeable increase of body weight and upper-arm skin fat has been noticeable in children, younger than 13 years.

Strel et al. (2003b) compared the results from the period 1990 to 2000 with the results from 2001 and found significant increase of body height and weight in both boys and girls. In the period 1990 to 2000 , body height in girls increased between the ages of 9 and $12(0.8 \%)$ and in boys twice: between the ages of 8 and 10 and between the ages of 13 and 15 . The average increase over a ten year period exceeded $1 \%$ of body height. Height acceleration has in the observed period been less significant than in the 1970 s and $80 \mathrm{~s}$. The largest increase of body weight in girls has been noticed at the age of $12(5.5 \%)$ and in boys between the ages of 11 and 14 (5\% over a 10-year period). It has been revealed that girls are heavier than boys at the ages of 12 and 13, which is a year earlier than in the 1980s (Strel et al. 1982). In this period the amount of skin fat has increased significantly in boys aged $12(10 \%)$ and girls aged $10(9 \%)$.

Strel et al. (2004) have found that body mass, body fatness and the number of overweight and/or obese children all increased over the period 1983 to 2003. Collected data for period 1970 to 2003 showed that young people experienced their biggest growth spurt one year earlier than their counterparts 30 years ago. Girls experienced their growth spurt of $7 \mathrm{~cm}$ between the ages of 10 and 11 , whereas boys experienced their biggest growth spurt of 8 $\mathrm{cm}$ between the ages of 12 and 13 . Nowadays, boys are taller by $5 \mathrm{~cm}$ and girls by $4 \mathrm{~cm}$ than their counterparts 30 years ago. Most of these changes were recorded in the period 1970 to 1983 , whereas in the last ten years stagnation can be noticed.

An extensive study by Brettschneider \& Naul (2004) has revealed that the findings concerning the amount and intensity of physical activity are remarkably consistent across studies and European countries: about two thirds of young Europeans do not take sufficient appropriate physical activity, the level of activity declines with age and is more pronounced in girls, data concerning the development of physical activity over the last decades indicate a decline in physical activity. Recent data show 
an emerging polarisation with the difference between fit and unfit young people increasing over time. This decrease may be a reflection of the rise in paediatric overweightness and obesity throughout Europe over the last 20 years rather than a true reduction in peak $\mathrm{VO}_{2}$. Though the definition of overweight and obesity, the assessment methods and the reference systems may vary from one survey to another, all findings confirm the rapid rise in the prevalence of overweightness in children and youth in most parts of Europe during the last decades.

A further study by Strel et al. (2006) compared the results of physical fitness and characteristics in the 2004/ 2005 and 2005/2006 academic years. As previously, the increase of skin fat in the observed periods amounted to approximately $2 \%$, with an increase of body weight by $1 \%$. Strel (2006) has found negative correlation between the aerobic endurance and body weight and upper arm skin fold. A cross-sectional study by Matton et al. (2007) generally revealed an increase in weight, stature, BMI, skinfolds and trunk-extremity index, and a decrease in the performance on several physical fitness tests.

A cross-sectional study, lasting between 1980 and 2006 Runhaar et al. (2010) revealed that 9- to 12-year old children in 2006 were significantly taller and heavier than their peers in 1980. The level of almost all neuromotor fitness variables has significantly decreased over the past 26 years.

The goal of the study was first, to find the tendency of changes in selected morphological characteristics of young male and female tennis players of various ages in the periods 1992-2000-2008; and second, to find the changes in selected variables of young tennis players and to compare them with the results of boys and girls of same age from normal school population.

\section{MATERIAL AND METHOD}

Sample of subjects. Within the project Measurement and counselling of sportsmen at the Institute of Sport at the Faculty of sport, University of Ljubljana, physical and mo- tor development of young male and female tennis players has been monitored since 1992. Analyses of annual testing (23 anthropometric measurements and 22 fitness tests of speed, agility, co-ordination, balance, flexibility, neuromuscular strength and power, aerobic endurance) of selected male and female tennis players - members of national junior teams and their correlation with the successfulness in tennis game has been presented in several studies Filipcic (1993), Filipcic (1996), Filipcic et al. (2005a), Filipcic (2009a) and Filipcic (2009b). The study included only those anthropometric measurements, which formed a part in both Sport-educational chart and Tennis player batteries of tests. Selected anthropometric measurements will be presented in detail in the chapter Sample of variables.

The sample of subjects represented two groups: sample of young tennis players and a large sample of primary and secondary schools pupils (boys and girls). Sample of school pupils consisted of all pupils participating in a project Sports education chart (Strel, 1996), representing around $80 \%$ of all pupils in Slovenian school population in the selected periods (1992-94, 1999-2001, 2006-08). Sample of tennis players consisted of all male and female tennis players divided in three age groups (12to 13 -years, 14- to 15-years, 16- to 17-years) who participated at annual measurements of anthropometrical and fitness tests of national team members organised by the National Tennis Association in the period from 1992 to 2008. Selection of tennis players of both genders has been carried out by the national team coaches who chose groups of measured subjects each year on the basis of achieved results (national and international ranking list, tennis performance).

Sample of variables. Sample of variables (Table I) included three variables, which were included in both Sports education chart and tennis measurement system.

Data analysis. Means and standard deviations were calculated for all groups. Differences between means of groups were tested with multivariate ANOVA (MANOVA) Wilks' lambda test, followed by univariate ANOVAs for all variables. PASW Statistics 18.0 was used for analysis.

Table I. Sample of variables.

\begin{tabular}{llll}
\hline Test & Code & Measured capacity & Measuring unit \\
Body height & Height & Longitudinal dimension of the body & $\mathrm{Cm}$ \\
Body weight & Weight & Volume of the body & $\mathrm{Kg}$ \\
Body mass index & BMI & Percentage of body mass & $\mathrm{Kg} / \mathrm{m}^{2}$ \\
\hline
\end{tabular}




\section{RESULTS}

An analysis of trends (Fig. 1) between the individual periods of measurement (1992 to 1994, 1999 to 2001, 2006 to 2008) revealed in male tennis players an increase in some of the tests and decrease in others; whereas sometimes so-called mixed (combined) trend has been noticed, indicating that in the second period (1999 to 2001) the trend is inverse with the first (1992 to 1994) and third (2006 to 2008) periods. Body height and body weight have decreased in the 12-13 years and 14-15 years groups of male tennis players, whereas in the group of 16-17 years old boys they increased. BMI decreased in tennis players from group 12-13 years, whereas in the age groups 14-15

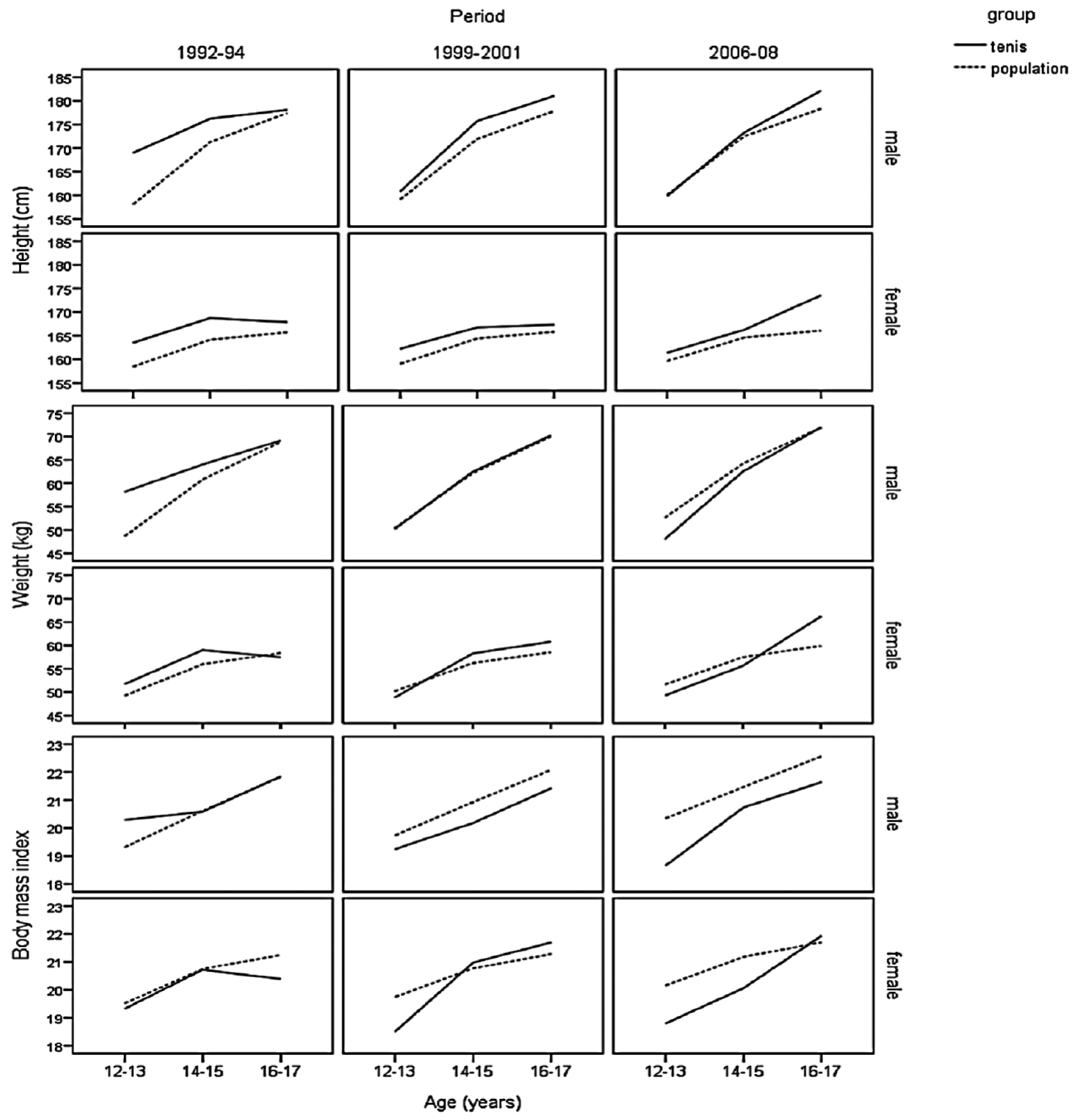

Fig. 1. Means of body height, weight and BMI by period, age, sex and group. 
years and 16-17 years the values in the period 1999 to 2001 decreased and in the period 2006 to 2008 the values increased.

In school population, boys of all ages are becoming taller and heavier from one period to another and the BMI is also increasing.

A comparison of trends between individual periods of measurements revealed that the body height in groups of 12-13 year-old and 14-15 year-old female tennis players is decreasing, whereas in a group of 16-17 year-old female players the trend of average values is mixed. The changes of values are even more diverse in body weight. Namely, in female tennis players from group 12-13 years the values decreased in the period 1999 to 2001 and increased in the last studied period. In 14-15 years group of girls, body weight decreased and then increased significantly in the oldest age group of girls. BMI values in female tennis players 12-13 years group in the period 1999 to 2001 decreased, whereas in the period 2006 to 2008 they increased. In contrast, in a group of 13-14 years girls the BMI values increased in the second time period and decreased in the last time period. In the oldest group of female tennis player the BMI values increased throughout the observed periods (Table II).

The results of the same age school girl's population revealed that the girls are becoming taller, heavier and have higher BMI values in every observed period (Table III).

Multivariate variance analysis (Table IV) revealed statistically significant differences in all main factors (group, age, gender and period) and additionally in interactions group-period, group-gender and age-gender. In other interactions the differences were not statistically significant.

Univariate variance analysis revealed statistically significant differences between the groups of tennis players and the same age school population for both genders. Statistically significant differences can be noticed in variables body height and BMI. A comparison of three age groups (12-13 years, 14-15 years, 16-17 years) revealed statistically significant differences between the groups in all three anthropometric variables. Differences between the genders indicate statistically significant differences only in variables body height and weight. A comparison of results for different periods did not reveal statistically significant differences.

Table II. Means, standard deviation (SD) and number of cases in a sample - male tennis players \& boys

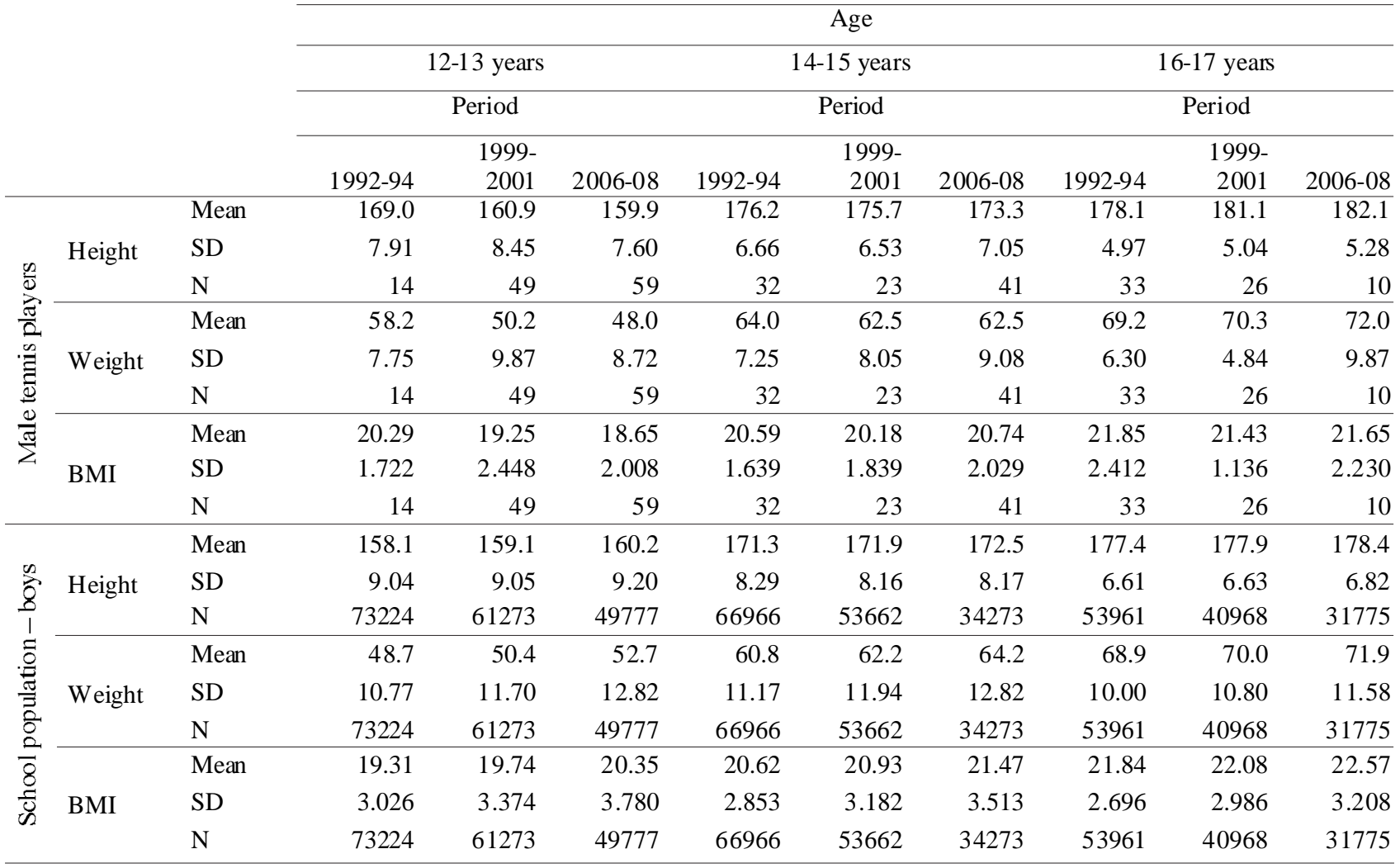


Table III. Means, standard deviation (SD) and number of cases in a sample - female tennis players \& girls.

\begin{tabular}{|c|c|c|c|c|c|c|c|c|c|c|c|}
\hline & & & & & & & Age & & & & \\
\hline & & & & $12-13$ years & & & $14-15$ years & & & 16-17 years & \\
\hline & & & & Period & & & Period & & & Period & \\
\hline & & & 1992-94 & 1999-2001 & 2006-08 & 1992-94 & 1999-2001 & 2006-08 & $1992-94$ & 1999-2001 & 2006-08 \\
\hline & & Mean & 163.5 & 162.2 & 161.4 & 168.8 & 166.8 & 166.3 & 167.9 & 167.4 & 173.6 \\
\hline & Height & SD & 6.38 & 7.25 & 6.45 & 2.57 & 4.81 & 6.06 & 1.59 & 5.09 & 5.49 \\
\hline$\overbrace{}^{2}$ & & $\mathrm{~N}$ & 12 & 57 & 48 & 11 & 30 & 30 & 4 & 16 & 9 \\
\hline$\frac{1}{\infty}$ & & Mean & 51.7 & 48.9 & 49.3 & 59.0 & 58.3 & 55.6 & 57.5 & 60.8 & 66.2 \\
\hline 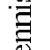 & Weight & SD & 6.23 & 6.59 & 7.93 & 5.33 & 5.41 & 8.17 & 4.94 & 4.69 & 8.89 \\
\hline $\begin{array}{l}0 \\
0\end{array}$ & & $\mathrm{~N}$ & 12 & 57 & 47 & 11 & 30 & 30 & 4 & 16 & 9 \\
\hline $\mathfrak{g}$ & & Mean & 19.33 & 18.51 & 18.80 & 20.72 & 20.98 & 20.06 & 20.39 & 21.69 & 21.93 \\
\hline & BMI & SD & 1.902 & 1.653 & 2.302 & 1.814 & 2.025 & 2.193 & 1.470 & 1.127 & 2.393 \\
\hline & & $\mathrm{N}$ & 12 & 57 & 47 & 11 & 30 & 30 & 4 & 16 & 9 \\
\hline & & Mean & 158.5 & 159.1 & 159.6 & 164.2 & 164.4 & 164.6 & 165.7 & 165.8 & 166.1 \\
\hline & Height & SD & 7.20 & 7.10 & 7.09 & 5.95 & 6.00 & 6.12 & 5.82 & 5.93 & 6.10 \\
\hline 010 & & $\mathrm{~N}$ & 69045 & 57678 & 46539 & 63844 & 49730 & 30910 & 56053 & 38239 & 30947 \\
\hline. & & Mean & 49.3 & 50.2 & 51.6 & 56.0 & 56.2 & 57.5 & 58.4 & 58.5 & 59.9 \\
\hline$\frac{\pi}{\bar{\Xi}}$ & Weight & SD & 9.57 & 10.25 & 10.96 & 8.56 & 9.29 & 9.97 & 8.08 & 8.74 & 9.32 \\
\hline $\bar{\varepsilon}$ & & $\mathrm{N}$ & 69045 & 57678 & 46539 & 63844 & 49730 & 30910 & 56053 & 38239 & 30947 \\
\hline 8 & & Mean & 19.52 & 19.75 & 20.16 & 20.75 & 20.77 & 21.18 & 21.25 & 21.28 & 21.70 \\
\hline$\overline{\bar{g}}$ & BMI & SD & 3.021 & 3.311 & 3.566 & 2.826 & 3.091 & 3.300 & 2.669 & 2.896 & 3.012 \\
\hline & & $\mathrm{N}$ & 69045 & 57678 & 46539 & 63844 & 49730 & 30910 & 56053 & 38239 & 30947 \\
\hline
\end{tabular}

Table IV Univariate and multivariate (MANOVA) F-tests for differences of group means ( $\mathrm{F}$ values, significant at 0.05 level are underlined).

\begin{tabular}{lrrrr}
\hline Source & height & weight & BMI & MANOVA \\
\hline Group & 59.5 & 2.4 & 6.4 & 68.2 \\
Age & $\underline{332.4}$ & $\underline{206.4}$ & $\underline{50.0}$ & $\underline{73.4}$ \\
Gender & $\underline{232.2}$ & $\underline{86.6}$ & 2.1 & $\underline{91.6}$ \\
Period & .8 & 1.5 & 0.8 & 5.9 \\
group*age & .4 & .1 & 0.4 & 1.6 \\
group*period & 2.2 & 2.5 & 1.9 & 4.7 \\
group*gender & .0 & .1 & .0 & 3.9 \\
age*period & $\underline{2.7}$ & 1.7 & 0.3 & 1.4 \\
age*gender & $\underline{61.6}$ & $\underline{17.1}$ & 0.6 & $\underline{11.6}$ \\
period*gender & .8 & .2 & 0.3 & .9 \\
group*age*period & 3.6 & 2.3 & 0.7 & 1.2 \\
group*age*gender & .3 & 1.1 & 0.7 & .3 \\
group*period*gender & 1.8 & 1.5 & 0.8 & 1.2 \\
age*period*gender & 1.3 & .7 & 0.9 & 1.2 \\
group*age*period*gender & 1.3 & .7 & 0.9 & 1.1 \\
\hline
\end{tabular}

\section{DISCUSSION}

The aim of the present study was to examine trends of changes across three time periods in the area of morphological characteristics of young tennis players and their peers from school population.

Body height. Body height in both male and female tennis players decreased from 5.6 to $1.3 \%$ in the age categories 12-13 years and 14-15 years, whereas in the group of 16-17 years-old male and female tennis players it increased by $2.3 \%$ and $3.2 \%$ respectively. Decrease of average body height in the age groups $12-13$ years and 14-15 years is undoubtedly unexpected, particularly considering very positive trends in school population. Two arguments can be used for this decrease in body height. First, tennis was a very popular sport in the 1980s, resulting in participation of a large number of extremely talented children with an above average anthropometric characteristics; the argument is supported with the results of study by Remih \& Tomc (1994). Second reason lies in the changes of characteristics in tennis game, which has become faster and more dynamic in younger 
categories (U12, U14). As a result, prominent body height is more of a hindrance than an advantage at a younger age. As serve is not yet a very important factor of success, an emphasis lies with speed and agility. A study by Müller (1989) has revealed a great importance of speed in tennis players of both genders, age 10 to 13, similar findings can be also seen in studies by Unierzyski (1994), Filipcic \& Filipcic (2005a) and Filipcic \& Filipcic (2005b), who explained with statistical significance competitive success of young tennis players of both genders, aged 12 to 14 years, with the tests of speed and agility. In addition, an importance of national coaches selection cannot be neglected, as the national team members were selected also (or mostly) on the basis of competitive successfulness (position on ranking list, tennis performance). The results of univariate variance analysis (Table IV) revealed expected differences between the groups of school population and tennis players in the variable body height. A comparison of average body height values of male tennis players and their peers from schools showed that tennis players were taller in all age categories, except in a group of 12- to 13-year-old boys in the period 2006 to 2008. As tennis players of both genders have to meet tough selection criteria, it was to be expected for them to be taller than their peers. Body height has a positive influence on competitive successfulness in young tennis players Filipcic \& Filipcic (2005a).

A comparison of three age groups revealed significant differences in body height (Table IV). In the group of 16-17 years-old tennis players, body height has in the period from 1992 to 2008 increased by $4 \mathrm{~cm}$ in male tennis players and by $5.7 \mathrm{~cm}$ in female tennis players. It can be concluded that the trend of changes in the average values of body height was to be expected. Average body height values of school population have increased both in boys and girls in all periods of measurement and in all age categories. An increase of body height was in the range of $0.2 \%$ to $1.3 \%$. Similarly, another study by Strel et al. (2003a) revealed an increase in longitudinal measurements of young people aged 7 to 19 in the period 1990 to 2000; however, the increase was not as large as a decade earlier (Stefancic et al.). The largest increase in body height has been noticed in the period 1990 to 2000 in the 12-year-old girls and 15-year-old boys (Strel et al., 2003b). In the period 1990 to 2000 two peaks of accelerated growth were not noticed, instead a significant increase in growth has been noticed from the age of 8 onwards, with the girls peaking at the age of 12 and boys at the age of 15 .

Between genders, expectedly significant differences have been noticed. When comparing body height, it can be noticed that particularly older male tennis players (14-15 and 16-17 years-old) are significantly taller than female tennis players with the exception of group of 12-13 years- old female tennis players, measured in the periods 1999 to 2001 and 2006 2008, who were slightly taller than the boys. The results corroborate with the findings of some researchers Strel et al. (2003b) and Stefancic et al., who concluded that girls between the ages of 11 and 13 develop faster than boys. After this period boys were taller than girls. A comparison of body height in boys and girls revealed that only in the 1992 to 1994 period $12-13$ years-old girls were by $0.4 \mathrm{~cm}$ taller than boys, which partially confirms findings by Stefancic et al. as well as by Strel et al. (2003b), stating that girls between the ages of 12 to 13 are taller than boys.

Differences in the average values of body height in the three age groups (12-13, 14-15 and 16-17 years-old), genders (boys, girls) and interaction age*gender have been discussed in numerous studies, which on one side indicate very intensive and diverse physical development and changes occurring between the ages of 11 and 17 and on the other hand consequences of biological differences between the boys and girls as well as differences in the pace of physical development.

Interaction of factors age*period indicates a significant influence of age and the period of measurement. This finding has also been confirmed by several studies, concluding that young people nowadays start to gain body height at an earlier age and also that they are taller than young people were in the past (Lindgren \& Hauspie; Runhaar et al.; Strel et al., 2003b; Strel et al., 2004).

Body weight. Body weight has significantly decreased in a group of 12-13 years-old and 14-15 years-old male tennis players in the period 1992 to 2008 (between 2.4\% and $21.2 \%$ ). In both male and female tennis players, aged 16 to 17 years, an average body weight has in the same period increased by $3.8 \%$ and $13.1 \%$ respectively. Lower body weight in younger age categories results in faster commencement of movements (split step and speed of acceleration), efficient positioning for shots (footwork, movement patterns) and change of directions (agility). Thus (Westerstahl et al.) found that increased body weight of young people resulted in worse results in movements, where body had to resist or overcome gravitational force (run, walk, jumps, sit-ups). Results indicate that the increase of body dimensions has contributed to both the decrease in aerobic fitness and the increase in muscular static strength, but not the decrease in muscular endurance.

Significant increase of average body weight in male tennis players, aged 16 to 17 years $(+2.8 \mathrm{~kg})$ and in female tennis players $(+8.7 \mathrm{~kg})$ substantiates the findings from the study by Strel et al. (2003b), which was carried out on a school population. This has also been verified with the results 
of univariate variance analysis (sTable IV), which did not reveal statistically significant differences between the observed groups of measured subjects. In the opinion of authors of present study the increase of body weight in tennis players is also a result of planned training process of strength and power, which increases muscle mass. However, to a certain extent in cases of extreme increase of body weight in tennis players, it can also be attributed to overweightness.

A comparison of two observed groups from the aspect of age (Table IV) revealed significant increase of body weight between different age groups (12-13, 14-15 and 16-17 yearsold). Increase in body weight is a trend, which has in school population been noticed already in the period 1970 to 1993; namely, in 1993 boys and girls were 10\% heavier than their peers in 1970 Strel et al. (2003b). This tendency has continued also in the period 1990 to 2000 , when significantly accelerated gain in body weight has been noticed in girls, aged 8 to 13 and in boys, aged 8 to 15 . The largest annual increase in body weight has been recorded in girls at the age of 12 and in boys at the age of 15 , mostly due to the increase in muscle mass.

Average body weight values have increased in both genders of school population in the period 1992 to 2008 by $2.5 \%$ to $7.5 \%$. A comparison of average results of individual variables between the young tennis players and their school peers revealed that expectedly selected and trained sportsmen generally achieved higher average values. This is particularly valid in male tennis players, aged 16-17 years (in all measured periods) as well as in female tennis players (periods 1999 to 2001 and 2006 to 2008). In groups of 1213 years-old and 14-15 years-old tennis players, measurements in the last period showed that both male and female tennis players are in average lighter in comparison with their school peers. Findings can be corroborated with the study by Kovac et al. (2007), which revealed that boys in average achieve lower average values in body height, whereas girls achieve higher values in body weight. Conclusions confirm the findings that regular sports activity in young male tennis players positively influences the regulation of body weight.

Findings from numerous studies revealed an increase in body weight as well as in the number of overweight children and youth (Dollman et al.; Freedman et al.; Lindgren \& Hauspie; Rasmuseen \& Johansson, 2000; Rasmussen et al.; Runhaar et al.; Troiano et al.; Wedderkopp; Westerstahl et al.). A phenomenon of not-optimal body weight is more often present also among the trained girls.

Differences between the genders (boys, girls) and interaction (age-gender) were to be expected. Both in body height and body weight reasons lie in earlier start of puberty in girls and biological differences between the boys and girls.

BMI. Differences between the young tennis players and school population revealed significant differences in average BMI values (Table IV), as higher values were in most cases recorded in boys and girls from school population. Slightly higher BMI values can only be noticed in groups of 12-13 years-old and 16-17 years-old male tennis players in the 1992 to 1994 period and in groups of 14-15 years-old and 16-17 years-old female tennis players in the period 1999 to 2001, as well as for the latter ones in the period 2006 to 2008. Some studies, examining the correlation between anthropometric characteristics and sports activity of young people did not reveal clear evidence for a relationship between BMI and physical activity Brettschneider et al. Similarly, Runhaar et al. found negative association between BMI and performance on neuromotor fitness tests, which suggested that increased BMI values cannot fully explain the inferior performance in neuromotor fitness test in 2006.

In contrast, Bronikowski (2006) found that quantity and quality of exercise influence the morphological (body composition, metabolism, oxygen uptake and consumption), somatic (body mass and height) and neurological (coordination, reaction time) characteristics of individuals. Recent studies have concerned relations between physical activity and motor and cardiovascular fitness, fatness, body mass, BMI and other body components in certain developmental stages. Similarly Westerstahl et al. does not exclude higher BMI value as one of the basic reasons for lower physical fitness.

Nevertheless, differences in average BMI values were revealed between three age groups, as the values were constantly increasing. Strel et al. (2004) has found that particularly after the age of 16 the BMI values begin to differ with gender.

Present study expectedly did not find any differences in the BMI values in relation to the period of measurements. Thus Westerstahl et al. investigated changes in 16-year-olds' fitness from 1974 to 1995. Both boys and girls in 1995 weighted more and had a higher BMI than in 1974. Similarly Troiano et al. has found that the largest increase in BMI values occurred in the period 1976 to 1980 . Strel et al. (2004) has found that the comparison of the results in the period 1983 to 2003 shows that in 1983 the percentage of children having an appropriate weight was about $10 \%$ lower than in 2003. The biggest percentage of overweight Slovenian children according to the BMI $\left(25-30 \mathrm{~kg} / \mathrm{m}^{2}\right)$ was found in 9-14 years-old boys and 8-13 years-old girls. Herman \& Groffik (2004) has interpreted the increase of BMI values 
in Polish children and youth with biological changes and improved life conditions in the society.

Changes in the observed morphological characteristics point to the increase in body height, body weight and BMI values in both school population and young tennis players. Whereas the negative changes in body weight and BMI values can be expected and understood in school population, this does not hold true for young tennis players, who are daily included in a training process.

Negative trends in morphological characteristics and physical fitness in young people have been noticed in various studies, stating changes in lifestyle as a main reason. Young people tend to be less sportingly active, they spend their free time passively, they sit down a lot of the time and have inadequate diets. All of the above resulted in increased body weight and lower physical fitness. It has been found that the amount of free time which young people use for sport is in correlation with their motor efficiency (Jurak et al., 2003). At the same time, differences also occur between genders, as boys are motorically more active than the girls (Brettschneider et al.; Jurak et al.; Jurak, 2006; Riddoch et al., 2004; Woodfield et al., 2002).
In addition, significant positive relationship between physical activity and cognitive functioning has to be mentioned Sibley et al. (2003). Physical activity is influenced by three domains (Jurak; Sallis \& Owen, 1999): interpersonal (biological, psychological and behavioural influences), social (family or peer support, modelling), and environmental (facilities, communities, accessibility, etc.).

In future, study will need to be upgraded with the comparison of results and findings from the study examining the changes in school population in the period 2001 to 2010.

\section{ACKNOWLEDGEMENTS}

Authors wish to express gratitude to Slovene Tennis Association and Institute of Sport at Faculty of Sport, University of Ljubljana and Ministry of Education and Sport, Republic of Slovenia. They have all kindly allowed an access to data on young tennis players and school population.

FILIPCIC, A.; LESKOSEK, B.; SARABON, N. \& FILIPCIC, T. Tendencias seculares en las dimensiones corporales entre tenistas jóvenes desde 1992 hasta 2008. Int. J. Morphol., 30(4):1558-1568, 2012.

RESUMEN: Diversos estudios han examinado las características y estado físico de niños y jóvenes. El objetivo de este estudio fue encontrar la tendencia de los cambios para determinadas características morfológicas de jóvenes tenistas (hombres y mujeres) de distintas edades, en los períodos 1992-2000-2008. Además, encontrar cambios en las variables seleccionadas de jugadores de tenis jóvenes y compararlos con los resultados de niños y niñas de la misma edad en la población escolar normal. Las variables de la muestra incluyeron altura y peso corporal e índice de masa corporal (IMC). El análisis multivariado de varianza reveló diferencias estadísticamente significativas en todos los factores principales (grupo, edad, sexo y periodo) y, además, en las interacciones de grupo-período, grupoedad y grupo-sexo. El análisis univariado de varianza reveló diferencias estadísticamente significativas en la altura corporal e IMC entre los grupos de jugadores de tenis y la misma población en edad escolar para ambos sexos y entre los tres grupos de edad (12-13 años, 1415 años, 16-17 años) para altura y peso corporal e IMC. Las comparación entre sexos indican diferencias estadísticamente significativas sólo en las variables altura y peso corporal. Los cambios en las características morfológicas observadas señalan un aumento de la altura y peso corporal e IMC tanto en la población escolar como en los jóvenes jugadores de tenis.

PALABRAS CLAVE: Tenistas jóvenes; Peso corporal; Altura corporal; Índice de masa corporal; Tendencias seculares.

\section{REFERENCES}

Brettschneider, W. B. \& Naul, R. Study on young people's lifestyle and sedentariness and the role of sport in the context of education and as a means of restoring the balance. Final report. Paderborn, University of Paderborn, Council of Europe, 2004.

Bronikowski, M. Profiles of intensity loads in physical education classes in Poland. Acta Univ. Palacki. Olomuc. Gymn., 36(1):47-57, 2006.
Dollman, J.; Olds, T.; Norton, K. \& Stuart, D. The evolution of fitness and fatness in 10-11-year-old Australian schoolchildren: changes in distributional characteristics between 1985 and 1997. Pediatr. Exerc. Sci., 11(2):108-21, 1999.

Filipcic, A. Zanesljivost in veljavnost izbranih motoric `nih testov v tenisu. Unpublished Master's thesis, University of Ljubljana. Ljubljana, Univerza v Ljubljani, Fakulteta za sport, 1993. 
Filipcic, A. Evalvacija tekmovalne in potencialne uspešnosti mladih tenis ${ }^{` k i h}$ igralcev. Unpublished doctoral dissertation, University of Ljubljana. Ljubljana, Univerza v Ljubljani, Fakulteta za sport, 1996.

Filipcic, A. \& Filipcic, T. The influence of tennis motor abilities and anthropometric measures on the competition successfulness of 11 and 12 year-old female tennis players. Acta Univ. Palacki. Olomuc. Gymn., 35(2):35-41, 2005 a.

Filipcic, A. \& Filipcic, T. The relationship of tennis-specific motor abilities and the competition efficiency of young female tennis players. Kinesiology, 37(2):164-70, 2005b.

Filipcic, A. Correlation of tennis motor skills and basic anthropometric characteristics and its influence on the competition successfulness of young tennis players Scientific approach in table tennis and tennis in Slovenia. Toronto, Sports Books Publisher, 2009a. pp.111-25.

Filipcic, A. Regression analysis of tennis-specific motor abilities and the competition efficiency of young female tennis players Scientific approach in table tennis and tennis in Slovenia. Toronto, Sport books publisher, 2009b. pp.127-41.

Freedman, D. S.; Srinivasan, S. R.; Valdez, R. A.; Williamson, D. F. \& Berenson, G. S. Secular increase in relative weight and adiposity among children over two decades: the Bogalusa Heart Study. Pediatrics, 99(3):420-6, 1997.

Herman, D. \& Groffik, D. Study on young people's Lifestyle and seden-tariness and the role of sport in the context of education and as a means of restoring the balance. Case of Poland. Katowice, Academy of Physical Education, 2004.

Jurak, G.; Kovac, M.; Strel, J.; Majeric, M.; Starc, G. \& Filipcic, T. Sports activities of Slovenian children and young people during their summer holidays Ljubljana. University of Ljubljana, Faculty of Sport, 2003.

Jurak, G. Sports vs. the "cigarettes \& coffee" lifestyle of Slovenian high school students. Anthrop. Notebooks, 12(2):79-95, 2006.

Kim, J.; Must, A.; Fitzmaurice, G. M.; Gillman, M. W.; Chomitz, V.; Kramer, A.; McGowan, R. \& Peterson, K. E. Relationship of physical fitness to prevalence and incidence of overweight among schoolchildren. Obes. Res., 13(7):1246-54, 2005.

Kovac, M.; Leskosek, B. \& Strel, J. Morphological characteristics and motor abilities of boys following different secondaryschool programmes. Kinesiology, 39(1):62-73, 2007.

Lindgren, G. W. \& Hauspie, R. C. Heights and weights of Swedish school children born in 1995 and 1967. Ann. Hum. Biol., 16(5):397-406, 1989.

Matton, L.; Duvigneaud, N.; Wijndaele, K.; Philippaerts, R.; Duquet, W.; Beunen, G.; Claessens, A. L.; Thomis, M. \& Lefevre, J. Secular trends in anthropometric characteristics, physical fitness, physical activity, and biological maturation in Flemish adolescents between 1969 and 2005. Am. J. Hum. Biol., 19(3):345-57, 2007.

Müller, E. Psychomotor tests for selecting those talented for tennis. Leistungssport, 19(2):5-9, 1989.

Rasmussen, F.; Johansson, M. \& Hansen, H. O. Trends in overweight and obesity mong 18-years-old males in Sweden between 1971 and 1995. Acta Pediatr., 88(4):431-7, 1999.

Rasmuseen, F. \& Johansson, M. Increase in the prevalence of overweight and obesity from 1995 to 1998 among 18-yearold males in Sweden. Acta Pediatr., 89(7):888-9, 2000.

Remih, A. \& Tomc, D. Ekspertni model usmerjanja in prvega izbora otrok $v$ tenis. Unpublished Bachelar's thesis, University of Ljubljana. Ljubjana, Univerza v Ljubljani, Fakulteta za sport, 1994.

Riddoch, C. J.; Andersen, L. B.; Wedderkopp, N.; Harro, M.; Klasson-Heggebo, L.; Sardinha, L. B.; Cooper, A. R. \& Ekelund, U. Physical activity levels and patterns of 9- and 15yr-old European children. Med. Sci. Sports Exerc., 36(1):8692, 2004.

Rowlands, A. V.; Eston, R. G. \& Ingledew, D. K. Relationship between activity levels, aerobic fitness, and body fat in 8- to 10-yr-old children. J. Appl. Physiol., 86(4):428-35, 1998.

Runhaar, J.; Collard, D. C.; Singh, A. S.; Kemper, H. C.; van Mechelen, W. \& Chinapaw, M. Motor fitness in Dutch youth: Differences over a 26-year period (1980-2006). J. Sci. Med. Sport, 13(3):323-8, 2010.

Sallis, J. F. \& Owen, N. Physical activity and behavioral medicine. Thousand Oaks, CA, Sage, 1999.

Sibley, B. A., \& Etnier, J. L. The relationship between physical activity and cognition in children: A meta-analysis. Pediatr. Exerc. Sci., 15(3):243-56, 2003.

Starc, G.; Strel, J. \& Kovac, M. Telesni in gibalni razvoj slovenskih otrok in mladine v s tevilkah: šolsko leto 2007/2008. Ljubljana, Ljubljana University, Faculty of sport, 2010.

Strel, J.; Sturm, J. \& Ambrozic, F. Ovrednotenje informacijskega sistema za ugotavljanja in spremljanje motoric `nih sposbnosti in morfolos `ih znac`ilnosti šolske mladine v SR Sloveniji. Ljubljana, Visoka s`ola za telesno kulturo, Ins`titut za kineziologijo, 1982.

Strel, J. Sportnovzgojni karton. Ljubljana, Ministrstvo za solstvo in sport, 1996.

Strel, J.; Kovac, M.; Jurak, G.; Bednarik, J.; Leskosek, B.; Starc, G.; Majeric, M. \& Filipcic, T. Nekateri morfoloski, motoricni, funkcionalni in zdravstveni parametri otrok in mladine $v$ Sloveniji v letih 1990-2000. Ljubljana, Fakulteta za sport, Ins`titut za kineziologijo, 2003a. 
Strel, J.; Kovac, M.; Rogelj, A.; Leskosek, B.; Jurak, G.; Starc, G.; Majeric, M. \& Kolenc, M. Ovrednotenje spremljave gibalnega in telesnega razvoja otrok in mladine $v$ solskem letu 2001 2002 in primerjava nekaterih parametrov sportnovzgojnega kartona s solskim letom 2001 ter z obdobjem 1990-2000. Ljubljana, Zavod za sport Slovenije, 2003b.

Strel, J.; Kovac, M., \& Jurak, G. Study on young people's lifestyle and sedentariness and the role of sport in the context of education and as a means of restoring the balance. Case of Slovenia - Long version. 2004. Available in: http:// www.fsp.uni-lj.si/didaktika

Strel, J. Correlation of physical characteristics and general endurace: A comparision of 7- to 19-year-old pupils between 1983, 1993 and 2003. Anthrop. Notebooks, 2(12):113-28, 2006.

Strel, J.; Kovac, M. \& Rogelj, A. Podatkovna zbirka Sportnovzgojni karton - porocilo za solsko leto 2005/2006 in nekatere primerjave s šolskim letom 2004/2005. Ljubljana, Fakulteta za sport, 2006.

Stefancic, M.; Arko, U.; Brodar, V.; Dovecar, F.; Juricic, M.; Macarol - Hiti, M. \& Tomazo - Ravnik, T. Ocena telesne rasti in razvoja otrok in mladine $v$ Ljubljani. Ljubljana, Institut za varovanje zdravja Republike. Slovenije, Oddelek za biologijo Biotehniske fakultete Univerze v Ljubljani, 1996.

Sturm, J. \& Strel, J. Primerjava nekaterih motoric `nih in morfolos $`$ kih parametrov v osnovnih s`olah SR Slovenije v obdobju 1970/71-83 - zakljuc`no poroc `ilo. Ljubljana, Institut for kinesiology, 1985.

Troiano, R. P.; Flegal, K. M.; Kuczmarski, R. J.; Campbell, S. M. \& Johnson, C. L. Overweight prevalence and trends for children and adolescents. The National Health and Nutrition Examination Surveys, 1963 to 1991. Arch. Pediatr. Adolesc. Med., 149(10):1085-91, 1995.
Unierzyski, P. Motor Abilities and Performance Level Among Young Tennis Players. Paper presented at the In Proceedings of the 3rd International Conference "Sport Kinetics '93". Poznan, 811 September 1993, Warsaw, 1994.

Wedderkopp, N. Atherosclerotic cardiovascular risk factors in Danish childern and adolescents. A community based approach with a special reference to physical fitness and obesity. Institute of sport science and clinical biomechanics, Faculty of health science, University of Southern Denmark, 2001.

Westerstahl, M.; Barnekow-Bergkvist, M.; Hedberg, G. \& Jansson, E. Secular trends in body dimensions and physical fitness among adolescents in Sweden from 1974 to 1995. Scand. J. Med. Sci. Sports, 13(2):128-37, 2003.

WHO. Global strategy on diet, physical activity and health. Copenhagen, World Helath Organisation, 2004.

Woodfield, L.; Duncan, M.; Al-Nakeeb, Y.; Nevill, A. \& Jenkins, C. Sex, ethnic and socio-economic differences in children's physical activity. Pediatr. Exerc. Sci., 14(3):277-85, 2002.

\section{Correspondence to: \\ Ales Filipcic \\ Faculty of Sport \\ University of Ljubljana \\ Gortanova 22, SI1000 \\ Ljubljana \\ SLOVENIA}

Email: ales.filipcic@fsp.uni-lj.si

Received: 16-03-2012

Accepted: 08-08-2012 